Obrazovanje odraslih/Adult Education, ISSN 1512-8784, Broj I - 2 2020., str. 37-56

UDK: $37.014: 316.42=111$

Pregledni rad/Rewiev paper

Primljeno/Received: 25. OI. $202 \mathrm{I}$.

Prihvaćeno/Accepted: I 5. 02. $202 \mathrm{I}$.

\title{
Conceptualizing Adult Identity Formation in Higher Education Context
}

\begin{abstract}
The main intention of this paper is to explore the possibility of positioning the discourse on adult identity formation within the context of higher education. To this end, first formational potential of higher education is revisited. Further on, Eriksonian psychosocial theoretical approach and Arnett's concept of emerging adulthood are proposed as the referential framework for conceptualizing adult identity formation processes. It is concluded that by offering institutionalized moratorium and the possibility for the extended transition from adolescence to adulthood, higher education context provides intensive identity work opportunities. However, in dominant discourses, higher education's humanistic ends have been suppressed by economistic and utilitarian objectives. Therefore, this paper also urges revitalizing higher education's humanistic values by exploring personal growth possibilities.
\end{abstract}

Key words: adult identity, higher education, emerging adulthood,

institutionalized moratorium.

${ }^{1}$ Amina Isanović Hadžiomerović, MA, Senior Assistant, Department of Pedagogy, Faculty of Philosophy, University of Sarajevo; e-mail: amina.isanovic@ff.unsa.ba 


\section{Introduction}

In its essence, education represents the process of cultivation, acquiring specific valuable knowledge, skills and competencies for purposeful living and effective functioning in demanding social and professional domains. Nevertheless, recent changes in higher education reflect restraint from the humanistic vision of education and confinement to economistic demands. It is obvious that education is witnessing the entrance of business principles, which are reflected in its mission and consumerist logic in treating knowledge and students. The value of higher education to students is seen through its capability to prepare them for the world of work and develop future graduates' occupational identity and work readiness. However, yesterday's world of work is by no means similar to the one we are witnessing today, and it might seem naïve to expect education to be capable of thoroughly preparing graduates to confront all complexities of tomorrow's labor market. Some views warrant that consumerist orientation in higher education can hinder students' development. "Approaching education as something to be served and consumed encourages a hedonic, extrinsic motivation for participating (e.g., Wexler, 1992), as opposed to an intrinsic motivation based on a love of learning, self-discipline, and mastery of experience (which are essential ingredients for ego strength)" (Côté \& Levine, 2002: 149).

Moreover, Arnold (2019) argues that the paradigm of students'preparation should be replaced with the paradigm of identity formation, suggesting that higher education's ends should be strengthening personhood and forming the personal identity of young people. An essential segment of development in higher education is related to the formation of adult identity. In the broadest sense, adult identity is "seeing oneself as an adult" (Macmillan, 2007: 20), and it lies in the core of intensive processes of personal identity formation in the years following adolescence.

In the theoretical works, when speaking about the "identity work" that an individual has to undertake, two formulations appear - identity discovery and identity construction (Waterman, 1993). The identity construction model focuses on the pragmatic value of identity processes, leading to successfully constructing such an identity that enables people to function and confront challenges in their social context. Hence, this model denies the existence of the 
true self and the substance inside a person that needs to be nurtured (Soenens \& Vansteenkiste, 2011: 381-382). It is more focused on the utilitarian value of identity processes, and it takes the social system as the point of reference. Unlike the construction model, identity discovery or identity formation focuses on identity "as a person's internal representation of who he/she is in terms of life goals, attitudes, and abilities" (ibid: 383). Identity is thus closely linked to the self, and identity formation is essentially a process of cultivating the self and discovering who one truly is.

\section{Formational Potential of Higher Education Experience}

Today's higher education is more accessible than ever before, with a tendency to open towards non-traditional students, lifelong learners, and social groups traditionally not considered university students. This tendency contributes to broadening the accustomed conception of a student and higher education purposes. Over the past century, higher education institutions began to encourage the enrolment of diverse groups of students. They are from the late 1980s referred to as non-traditional learners (OECD, 1987), or in more recent works as post-traditional learners (Soares, 2013). Their distinctiveness is expressed in multiple ways; untypical socio-economic background, family history, prior educational biography, or more mature age than is typical for a student cohort. Non-traditionality is also manifested in using diverse learning paths and modes, previously not considered legitimate in higher education (e.g., work-place learning, multimedia learning, digital media learning). Besides, diverse students bring their multiple identities into the educational processes. They include adults who are commonly wage earners for themselves and their families, combining work and learning, pursuing knowledge, skills, and a credential that employers will recognize, and seek academic/career advising to guide their professional path. Given the rising presence of non-traditional/post-traditional students, new research venues into adult identity formation and development of this group of students are emerging for more nuanced investigation. This is especially important given the findings that personal development through higher education shows "benign and transformative" (McLean \& Abbas, 2011: 2), but also "negative and damaging" (ibid) effects on identity development. However, focusing on the 
context of non-traditionality is beyond the scope of the present paper, which intends to set the framework for conceptualizing adult identity formation of students transitioning from adolescence.

With massification and widening access to higher education, participation in post-secondary education has become an accustomed route for a more significant portion of young people after graduating from high school than it used to be generations ago. Years spent in higher education cover a significant part of the transition from adolescence to adulthood, for some even representing a station lunching them into adulthood. Higher education for most students provides a "vestibule", when assuming adult roles and tasks is suspended. Expansion of post-secondary education is also often related to "delayed or jeopardized labor market integration" (Brückner \& Mayer, 2005: 30). For youths attending some form of post-secondary education, socialization and education interact with their personal development processes. Educational experience can hinder or discourage the critical processes in adult identity formation in such an interplay. However, so far, studies examining the role of educational settings in the processes of students' personal identities development have shown "the potency of identity as a concept at the core of educational processes" (Flum \& Kaplan, 2012: 244), opening space for discussing processes of identity formation in various educational contexts, including higher education. Research has not fully addressed how educational contexts shape the perception of adult status or contribute to its cultivation (Syed \& McLean, 2015; Gilleard \& Higgs, 2016). Especially, little is known about how higher education impacts the identity formation of non-traditional/posttraditional students.

Furthermore, summarizing from a number of longitudinal studies, Adams and Fitch (1983) conclude that higher education years are "an important time for continued personality formation" (ibid: 1267). This finding signals the formational potential of higher education and leaves open the question of whether the actual processes in it claim that potential. The importance of the context, particularly that of educational institutions, for the process of identity formation has been already recognized (Lannegrand-Willems \& Bosma, 2006). Furthermore, Brückner and Mayer (2005: 32) argue that education and labor market institutions are key actors nowadays in structuring the life course, which governs individuals' age-graded behavior. Waterman (1993) suggests that the 
higher education context provides "a diversity of experiences that can both trigger considerations of identity issues and suggest alternative resolutions for identity concerns" (ibid: 53-54). However, it remains open to the question of the particular aspects in which higher education acts as a resource and support to students on the path of their adult identity formation.

Starting higher education represents a threshold in youth's lives. It often includes other transitions (leaving the parental home, independent living, and socializing in new peer groups), which challenge individual identities requiring a higher degree of reliance on personal psychological capacities while breaking up with adolescent forms of responses and adopting adult-like ones. This challenge is regarded as "identity reformation process" (Kroger, Martinussen \& Marcia, 2010). However, reforming one's identity takes time and requires resources, both from within and from the outside. In this sense, the educational process should be designed and governed so that it recognizes students' personal inner struggles on their road to adulthood. Students differ in their readiness for higher education, psychological maturity, and agency, which can influence their adult identity formation (Côté, 2006) and might require additional intentional support from an educational institution.

Educational context is essential for shaping young persons' self-image, modeling their behavior, and acquiring a sense of self-efficacy. Research by Lannegrand-Willems and Bosma (2006) documented this in the context of secondary education and identity development in adolescents. Their study demonstrates that school experience acts as "a personal resource in the development of identity" (ibid: 85). On the other side, when it comes to previous research on higher education context, in a voluminous study on How College Affects Students (Pascarella, 2006), which was initiated by Pascarella and Terenzin two decades ago, it is interesting that authors provide little evidence of the effects related to identity development, not to mention adult identity specifically.

Among the rare studies, Berman, Kennerley and Kennerley (2008) focus on adult identity as an outcome variable while researching the effects of a university-based intervention program. Their research tells how a particular learning design (co-participatory and transformative) brings positive changes in students' adult identity development. Results suggest that students are interested in self-growth and are motivated to participate in such activities while in higher 
education, perhaps equally as they are interested in the main study program. However, higher education is slowly opening itself towards non-traditional forms of learning such as blended learning, MOOCs, e-learning, or group projects. Moreover, today's tertiary education is wedged in "didactical antiquity", in which students are confined to "learning requirements that have nothing to do with them and their self-learning movements" (Arnold, 2019: 12). While the learnercentered paradigm is a well-established approach in adult education, its position in higher education is not as favorable. In this paradigm, a teacher is not an unquestionable authority but a facilitator, while a student is active knowledge and meaning constructor. Such a teaching experience aims to be relevant for students personally - from the content, resources, methods, and environment - and, as such, opposes the traditional learning culture. Nevertheless, its values for students' personal growth are many. Based on the systematic analysis of literature on student-centered approach, Tangney (2013) identifies, among other elements, values of this paradigm for students' personal growth; opportunities for empowerment, respects for students' free choice and responsibilities, and expressing faith in students' potentials (ibid: 268-269).

The discussion on adult identity in higher education further leads us to clarifying interactions between social context and individual agency in the processes of adult identity formation. This theme has already been recognized as of particular value for considering the transition from adolescence to adulthood, as it is reflected in the volume edited by Ross Macmillan (2007). Summarizing from a bulk of different interpretations, Hitlin and Elder (2007: 172) identify two characteristics of agency - moments of freedom and the ability to initiate selfchange, in addition to four aspects of agency suggested by Bandura: intentionality, forethought, self-reactiveness (self-regulation), and self-reflectiveness (ibid). This implies certain individual powers that stipulate person's developmental processes and interact with the resources and activities coming from the social context. The sense of personal agency, along with the sense of direction and purpose signals "positive adjustment and optimal functioning" (Berman, et al., 2008: 139). Besides, studies (e.g., Flum \& Kaplan, 2006) document the benefits of exploratory process in an educational setting by providing students with adaptive outcomes, e.g., the ability to respond to situations that challenge their identities, which is needed throughout life, whenever one's identity is at the question. Moreover, 
researching in the school context, Lannegrand-Willems and Bosma (2006: 86) argue that exploration and commitment are inseparable from participation in important societal institutions.

\section{Students on Road to Adulthood}

Studies cited so far provide evidence supporting active psychological processes of self-exploration, questioning, and experimentation in students attending higher education. Furstenberg (2008) goes as far as to claim that over the past decades, higher education became the central social institution that structures early adulthood. In effect, it provides prerequisites for the transition to adulthood, enabling access to better-paid jobs and more flexibility in governing one's career. There are also countries like Bosnia and Herzegovina where higher education becomes a station even to those youth who never aspired to this educational level but are choosing for it due to lack of employment opportunities. This role of higher education has already been described as "parking lot" (Thunborg, Bron \& Edström, 2013). However, the global trend is that an average person in the early twenties spends five years more in education than the previous generations. Likewise, "educational experiences of those now in their early 20s resemble those who were in their late teens 50 years ago" (Côté, 2006: 89). Youth representing a group of higher education students are described (e.g., Furstenberg, 2013: 35) as having different transitions to adulthood than their counterparts not pursuing higher education. Persons embarking on work-related commitments after high school might enter adult marking roles earlier, but it is expected that even in this case, the transition is longer than it was generations before due to high demands of independent living.

Moreover, researching the inputs and throughputs of students' development in higher education, Côté and Levine (2002) show that prevailing motivation for attending higher education among students nowadays is extrinsic, with passive motivational profiles of expectations driven and default driven students. In the latter case, students are attending higher education because of the lack of alternatives, while in the former to please their parents (ibid: 150-151).

However, as stated earlier, research on the adult identity formation of higher education students is peculiarly scarce compared to adolescent development or 
the context of secondary education. According to Côtés (2006) findings, adult identity development scores increase linearly between 18 and 23, with about 53\% of students aged 23 having moderate adult identity scores and $41 \%$ scoring for a high adult identity. Kroger, et al. (2010) found that one-third of students reach full identity achievement upon completing higher education. Those findings suggest that youth in higher education are somewhere in-between adolescence and full adulthood. Likewise, the cited results indicate that higher education does not have the same effects on all students and that some other factors partake jointly with higher education experience. Benson and Elder (2009) go as far as to maintain more significant variability in youth's pathways to adulthood, stressing the importance of "social support and social psychological resources" (ibid: 1265).

Prior studies (e.g., Holmstrom, Karp \& Gray, 2002) have already documented that higher education faces students with upheaval in daily matters more than coursework complexities. In longitudinal research over three years with psychology students, the same authors also found out that students were reporting on becoming more independent and self-accountant "but at a comfortable and relatively unthreatening pace" (ibid: 454). This suggests that students perceive higher education years as a supportive context providing a niche for their personal developmental journey. It has been widely recognized that youth participating in higher education are undergoing emerging adulthood, facing many challenges and opportunities on the road to becoming an adult.

Although existing studies provide limited insight into the transition experiences, they give no indications of the role of higher education experience in forming an adult identity. Some research (cf. Benson, Johnson \& Elder, 2012) confirms relatedness of school and work statuses to subjective adult age in the early twenties, whereby persons who were out of school and having a job tended to perceive themselves as adults to a greater extent compared to those with different school and work statuses. The same study also confirmed that youth's self-perception of adult identity attainment should be observed concerning several developmental processes, psychological maturity, and school-to-work pathways.

For most student populations, marriage and parenthood are not desired tasks during their college years, while most of them leave their parental households managing their everyday life matters and finances more or less independently of their parents. In a study with senior high school students transiting to higher 
education Holmstrom et al. (2002: 438) found that the students were much more concerned with the responsibilities of an independent living, like doing laundry, organizing daily routine, budgeting money, friendships and renegotiating relationships with family than they were concerned with academic challenges. It was also reported that leaving parents' home for college poses a set of identity questions before the youth who find themselves "negotiating a delicate balance of independence and dependence, autonomy and reliance on others, distance and closeness, change and stability" (Holmstrom et al., 2002: 255).

Among the most remarkable findings from Arnett's research (Arnett, 2004) with higher education students is that they tend to feel like adults in specific ways but not in all, e.g., they tend to feel in-between, which lead to the formulation of emerging adulthood theory that will be discussed later. This leads to a hypothesis that the role of a student provides the most important identification for youth attending higher education, granting thus a niche that suspends entering other developmental tasks that might endanger their student status. They might be working to gain some financial independence and valuable experience, but not full-time and not in a career-based way. They might enter relationships in order to explore themselves and possible partners but delaying marriage and parenthood. Arnett (2004) identified the three central developmental tasks that arise for emerging adults: finding a satisfying career, choosing a partner for starting a family and establishing financial independence. All those tasks are considered to be a part of exploratory behavior while restraining from long-lasting commitments. Most of the students, at least during their college years, live independently of their parents and are entitled to certain financial responsibilities. However, not all of them manage to obtain financial independence from their parents, given limited job opportunities and sometimes demanding workload in their studies.

\section{Students as Emerging Adults}

Although earlier theorists such as Havighurst, Erikson, Chickering and Reisser have pointed to the need for more nuanced differentiation of the phases of human development, especially in the transition from adolescence to adulthood, only the concept of emerging adulthood introduced by Jeffrey Arnett in the late 1990s has witnessed affirmation in empirical studies (e.g., Reifman, 
Arnett \& Colwell, 2007). Therefore, in the more recent literature (cf. Hartmann \& Toguchi Swartz, 2007; Toguchi Swartz, Hartmann \& Rumbandt, 2017), especially that related to the context of higher education, emerging adulthood is treated as a distinct phase in human development placed "around age 18 and stretching into the early 30s" (Toguchi Swartz et al., 2017: 2). Recently, Arnett's concept of "emerging adulthood" is gaining prominence in use, emphasizing the liminal position between adolescence and adulthood. Notwithstanding the critics of the concept, it is relevant for stressing "the extension of identity issues from adolescence into emerging adulthood" (Schwartz et al., 2013: 107). By this, the processes of identity exploration and commitment are rendered as "the most central feature" of this period (Arnett, 2004: 8).

Researching with young people between 18 and 25, Jeffrey Arnett (2004) has concluded that there is a specific period of life, which is neither adolescence nor "full" adulthood. He named this period emerging adulthood, encompassing the time when persons think of themselves as grown-ups, but they are still not considered mature enough to be adults. When asked whether they have reached adulthood, young people aged 18-25 respond "yes and no". Emerging adulthood is "distinguished by relative independence from social roles and normative expectations" (Arnett, 2000: 469). This phase begins with high school graduation, and it continues with many transitions in an individual's life. However, the endpoint is tensile, reflecting various individual paths and trajectories, giving this period "remarkable amorphousness" (Schwartz et al., 2013: 97).

The generation under the focus of Arnett's study is characterized by a higher level of freedom, questioning, and unpredictability in the transition to adulthood, which carries a series of demographic and psychological challenges. Some of the challenges are related to public policies regarding tenure and education of the generation that needs more time to become a productive segment of the society, make money and pay taxes. In the psychological sense, the challenge is in the possibilities of developing the sense of autonomy, responsibility for own personal development, but also for other roles that are considered worthwhile in a particular social context, such as the role of employee, spouse, a parent, and the like.

Critics of Arnett's concept have been directed to viewing emerging adulthood as a developmental stage and its aspirations towards theory status 
(Côtè, 2014; Syed, 2016). In this regard, Syed recognizes integrativity and generativity as the main strengths of emerging adulthood, but questions its explanatory power needed for the status of a theory (Syed, 2016: 22). The same author, referring to the streams in developmental science from the 1980s onwards (life course theory, life span theory, developmental contextualism, and dynamic systems), warrants that "stages are not good" (ibid: 14) for they imply universality, normativity, and discontinuity in development, and have been abandoned in recent conceptualizations of human development. Côtè (2014) adds to the list of disputes stating that exploration before taking adult commitments, or moratorium in Erikson's terms, is not something that the whole generation will undertake. Besides, his positions did not prove to be invariant across the social classes. Arnett's conception omits antecedents and long-term consequences of identity formation processes, which is another remarkable limitation according to Côtè (2014: 187).

Based on the intensive research on the topic of emerging adulthood, Arnett (2000; 2004) extracted five dimensions that distinguish this period;

- feeling in-between - most emerging adults feel that they are no more adolescents, but they do not feel as full adults either

- identity exploration - emerging adults are actively exploring themselves in the domains of world-view, career, relationships, and learning "who they are and what they want out of life" (Arnett, 2004: 8)

- self-focus - emerging adults are gaining more independence and responsibilities for themselves; they are focused on fulfilling their own needs

- age of possibilities - for most people, this is an optimistic age; a person sees a number of possible partners, job opportunities, social goals

- age of instability - many possibilities and choices that have to be dealt can make a person confused; confronted with change, some persons can feel discomfort, while others can feel a lack of self-confidence and personal freedom; a person is confronted with choices regarding living arrangement, education, job and choosing partners.

Empirical research in emerging adulthood is still in its early days. Some of the pioneering studies (Reifman et al., 2007) affirm differentiation of the 
period between 18 and 25 years based on the given characteristics compared to younger and older groups. A logical question arising from the earlier discussions is whether emerging adulthood as a separate phase of life actualizes mainly in cases of the delayed entrance to "full" adulthood or represents the phase to which are entitled all, regardless of their individual's contextual variables developmental trajectories. The more and more visible differentiation of a group of young people who neither participate in education nor are employed (NEET) makes more complicated attempts of a precise and clear definition of developmental paths and trajectories in the transition from adolescence to adulthood. Arnett's model was also criticized for overemphasizing perceptions and the inner side of the transition to adulthood, failing to account for demographic and objective markers contextually (cf. Côtè, 2014: 182). A limitation that Arnett himself noted is its relatedness to the specific context, that is: Western, developed countries and elite youth attending higher education, saying that it is "a period that exists under certain conditions that have occurred only quite recently and only in some cultures" (Arnett, 2004: 42). Syed and Mitchell (2013) indicate in this regard that no straightforward generalizations can be made on the existence and features of emerging adulthood to young adults with different ethnical backgrounds. Therefore, more research is needed to illuminate emerging adulthood among youth originating from different social backgrounds and different cultures.

As was shown thus far, the concept of emerging adulthood contributes with descriptions of young people finding themselves in post-adolescent years but not reaching for full adulthood, which is mostly found among the youth enrolled in higher education. A series of studies conducted by its inventor reflects searching for one's adult identity while experimenting with varieties of options without making firm commitments. Just as the freedom to explore might resonate positively, the lack of guiding structures and norms in this process might be threatening, as Erikson himself suggested (Erikson, 1968). This gives an argument for looking at the role of social structures such as higher education in this regard. 


\section{Higher Education as Institutionalized Moratorium}

As it is contained in Erikson's theory, identity development is a lifelong process, meaning that persons will be faced with various transitions throughout their lives, which will challenge their already established answers to the key identity questions. Also, given the epigenetic principle of human development proposed by Erikson's theory, it is maintained that present developmental tasks build upon the previous conflicts and attainments. Eriksonian tradition posits exploration and commitment as the two main processes of identity formation, which are inseparable from the social context. In this view, exploration represents a process of information gathering that precedes making choices and commitments. A person pursues information both on her/his personality and the context. Higher education context provides this pursuit with "tangible resources" (Côté, 2006), representing a structured and organized environment for students' self-growth. Discussing the role of social context for the development and maintenance of the sense of ego identity, Erikson (1968) stresses the importance of recognition and support from the social environment. Fundamental are interactions with significant others and social institutions as the source of strength for ego. In an earlier study, Adams and Fitch (1983) were interested in what they referred to as psychological environments of university departments characterized by the three dimensions defined by Moos (Moos, 1973 cited after Adams \& Fitch, 1983: 1266). First is the relational dimension, which embeds interactions and support from relations among people in a certain environment. Then comes the dimension of personal development, meaning that an environment supports the processes of personal development. The last one is the dimension of system maintenance, providing order and organization to various processes at play. Through its structures and processes, educational context provides a framework for students' exploration of their identities and search for new questions about who they are. Even the negative experiences should not be dismissed from the growth potential and possible developmental effects by activating "the ability to recast a negative memory as a positive turning point or learning experience" (Schwartz et al., 2013: 97). 
So far, we have seen that the processes of adult identity formation in higher education students are inseparable from their role of a student and educational context. We have discussed that the process of adult identity formation includes a series of crises or conflicts that a young person has to resolve in order to move on with her/his identity development. Crises resolution undermines exploratory behavior before taking on firm commitments and claiming identity achievement. This all reflects an intensive "identity formation work", which, according to Erikson (1968), requires a psychosocial moratorium. Moratorium effects of higher education setting are manifested in the developmental delay. Opposite are acceleration effects when development is enhanced (Côté, 2002: 120).

Moratorium itself represents "a period of delay granted to somebody who is not ready to meet an obligation or forced on somebody who should give himself time" (Erikson, 1968: 157). The main goal of the psychosocial moratorium is "free role experimentation [...] in some section of his society" (Erikson, 1959: 111). The concept of moratorium denotes the possibility for persons to "seek out and explore various possible identity commitments" (Berman, et al., 2008: 141). When exploration processes are high, while commitments are not yet taken, it means that identity formation processes are active, but during the moratorium period, identity is not yet achieved. Commitments typically result from exploration, but it is not in all cases this way. Côtè (2014) indicates that "neither Erikson nor Marcia argued that all young people pass through such a period of undertaking active identity explorations" (ibid: 187).

Further, this gives rise to an individual's agency, especially in those youth involved with institutions in some crucial periods of their identity development. The lack of active exploration, while a person is in a state of prolonged transition to specific roles and tasks (e.g., occupational and familial), is what Cuzzocrea (2018), in her research with Italian youth, identifies as waithood, as opposed to the moratorium, which is expressed in active exploration. She defines waithood as "intermediate passages deprived of their intrinsic exploratory value" (ibid: 15), so persons are waiting until it passes. Institutional support from the environment might be of crucial value in helping youth make use of the opportunities that the period between adolescence and adulthood grants. This support is viewed in literature through facilitation providing resources (in terms of equipping individuals with cognitive capacities and individualization strategies) or as an investment that individuals make in their identity. 
Erikson posited that societies provide youth with a structured framework to guide them on the path to adulthood by providing exploration and development opportunities, representing an institutionalized moratorium. One example in higher education would be granting students opportunities to change academic majors or encourage more mature meaning-making in the teaching process (cf. Schwartz et al., 2013: 97). On the other hand, Erikson also maintained that psychosocial moratorium could be self-constructed by youth. The selfconstructed moratorium, just as the one which is imposed on the youth, can be a source of social problems and threatening if it takes young persons away from social values and norms. Erikson assumed that institutions provide "the necessary matrix of the development of all behaviour" (Kroger \& Marcia, 2011: 32). In Côté's (2006) interpretation of Erikson's theoretical positions, institutionalized moratorium provides a safe zone for "working through identity confusion and resolving an identity crisis" (Côté, 2006:85). The institutional moratorium can have a double role - the institution itself in a way creates the moratorium by preventing taking commitments outside its framework, while in the other sense, it provides a shelter, support for those in need for more time to explore themselves before making long and firm commitments.

\section{Conclusions}

Based on what has been said thus far, it can be concluded that current discourse expands awareness and tolerance of non-traditional and off-time transitions to adulthood. Therefore, youth in higher education are somewhere in-between adolescence and full adulthood, given that the processes of becoming, exploration and questioning identity, searching for what one truly is are intensive. The role of higher education in students' adult identity formation in this paper is viewed through the concept of the institutionalized moratorium. Analogous with Erikson's psychosocial moratorium, institutionalized moratorium provides structure and resources to students in their identity exploration processes. Erikson's theory underpins relationships with others, recognition and support from the environment in providing students with adaptive outcomes enabling them to respond to situations that challenge their identities. The teaching approach is reported as having formational potential when it is student-centered, cognitively, 
emotionally and socially challenging, and when it grants students the sense of self-directedness in learning. Analyses provided in this paper give evidence that higher education is an important context for ongoing personality formation since it faces students with challenges both in personal and academic life. Reviewed studies also suggest that students are interested in self-growth while in higher education, perhaps equally as they are interested in the main study program, and that they need support and resources from their environment. Implications for higher education's formational potential are seen in Arnold's (2019) urge that the paradigm of identity formation (instead of the paradigm of preparation) should be promoted in educational contexts, suggesting that higher education's end should be strengthening personhood and forming the personal identity of young people.

During the past decades, higher education has witnessed massive transformations moving from elite to nearly universal in most societies, admitting students of diverse backgrounds, academic preparedness, and motivation. In the face of those changes, the purpose and the mission of higher education are also being re-defined, expressing its inclination towards industry and economy, and setting preparation of students for the labor market as its utmost goal. Furthermore, the mainstream discourses on higher education seem to neglect students' personal development as the educational goal, ignoring the role it could play in that process. Conversely, as Arnold (2019) notes, facing the uncertainty of the present and the future will require higher education to focus more on personality and extra-professional competency development.

The present paper tackled the formative potential of higher education. It dealt with its capacity to shape young persons' character attributes and develop personal properties needed for more independent and autonomous adult living. This objective contrasts the prevailing perception of higher education as being concerned exclusively with academic goals related to scientific discipline or imparting professional knowledge leading to a qualification. The rationale for raising such a question stems from the fact that higher education is the only social institution entitled for systematic education of youth undergoing adult identity formation processes. This further opens the question of whether the actual processes in higher education claim their formational potential, a question that should be addressed in a thoroughly designed empirical research. 


\section{Konceptualizacija formiranja identiteta odraslosti u kontekstu visokog obrazovanja}

Sažetak: Osnovna namjera ovoga rada jeste istražiti mogućnosti pozicioniranja diskursa o formiranju identiteta odraslosti unutar konteksta visokog obrazovanja. U tu svrhu, najprije se preispituje formativni potencijal visokog obrazovanja. Zatim se predstavljaju Eriksonov psihosocijalni teorijski pristup te Arnettov koncept nadolazeće odraslosti kao referentni okviri unutar kojih je moguće promišljati procese formiranja identiteta odraslosti. U zaključku se navodi kako visoko obrazovanje pruža institucionalizirani moratorij, kao i mogućnost produženog prelaska iz adolescencije u odraslost, te tako kreira prostor za intenzivan proces formiranja identiteta. Ipak, čini se kako su u dominantnim diskursima humanističke svrhe visokog obrazovanja potisnute neoliberalnim ciljevima. Stoga, ovaj rad također poziva na povratak humanističkim vrijednostima u visokom obrazovanju ukazujući na mogućnosti razvoja osobnosti u tom kontekstu.

Ključne riječi: identitet odraslosti, visoko obrazovanje, nadolazeća odraslost, institucionalizirani moratorij. 


\section{References}

Adams, G. R., \& Fitch, S. A. 1983. Psychological environments of university departments: Effects on college students' identity status and ego stage development. Journal of

Personality and Social Psychology, 44(6), pp. 1266-1275.

Arnett, J. J. 2000. Emerging adulthood: A theory of development from the late teens through the twenties. American Psychologist, 55, pp. 469-480.

Arnett, J. J. 2004. Emerging Adulthood: The Winding Road from the Late Teens through the Twenties. New York, NY: Oxford University Press.

Arnold, R. 2019. Escape from Teaching. Lanham: Rowman \& Littlefield.

Benson, J. E., \& Elder, G. H. 2011. Young adult identities and their pathways: A developmental and life course model. Developmental Psychology, 47(6), pp. 646-1657.

Benson, J. E., Johnson, M. K., \& Elder, G. H. 2012. The implications of adult identity for educational and work attainment in young adulthood. Developmental Psychology, 48(6), pp. 1752-1758.

Berman, S. L., Kennerley, R. J., \& Kennerley, M. A. 2008. Promoting adult identity development: A feasibility study of a university-based identity intervention program. Identity: An International Journal of Theory and Research, 8(2), pp. 139- 150 .

Brückner, H., \& Mayer, K. U. 2005. De-Standardization of the Life Course: What it Might Mean? And if it Means Anything, Whether it Actually Took Place? Advances in Life Course Research, 9, pp. 27-53.

Côté, J.E. \& Levine, C. 2002. Identity formation, agency, and culture: A social psychological synthesis. Mahwah, NJ: Lawrence Erlbaum Associates.

Côté, J.E. 2006. Emerging adulthood as an institutionalized moratorium: Risks and benefits to identity formation. In: Arnett J. J. \& Tanner J. L. eds. Emerging adults in America: Coming of age in the 21st century. Washington: American Psychological Association, pp. 85-116.

Côté, J. E. 2014. The Dangerous Myth of Emerging Adulthood: An Evidence-Based Critique of a Flawed Developmental Theory. Applied Developmental Science, 18(4), pp. 177-188.

Cuzzocrea, V. 2018. Moratorium or waithood? Forms of time-taking and the changing shape of youth. Time \& Society, 28(2), pp. 567-586.

Erikson, E. H. 1968. Identity: Youth and Crisis. New York: Norton \& Company, Inc.

Erikson, E. H. 1959. Identity and the life cycle: Selected papers. New York: International University Press. 
Flum, H. \& Kaplan, A. 2006. Exploratory Orientation as an Educational Goal. Educational Psychologist, 41(2), pp. 99-110.

Flum, H., Kaplan, A. 2012. Identity Formation in Educational Settings: A Contextualized View of Theory and Research in Practice. Contemporary Educational Psychology, 37, pp. 240-245.

Furstenberg, F. F. 2008. The intersections of social class and the transition to adulthood. New Directions for Child and Adolescent Development, 2008(119), 1-10.

Furstenberg, F. F. 2013. Transitions to Adulthood. The ANNALS of the American Academy of Political and Social Science, 646(1), pp. 28-41.

Gilleard, C., \& Higgs, P. 2016. Connecting Life Span Development with the Sociology of the Life Course: A New Direction. Sociology, 50(2), pp. 301-315.

Hartmann, D., \& Toguchi Swartz, T. 2007. The New Adulthood? The Transition to Adulthood from the Perspective of Transitioning Young Adults. Advances in Life Course Research, 11, pp. 253-286.

Hitlin, S., \& Elder, G. H. (2007). Time, Self, and the Curiously Abstract Concept of Agency. Sociological Theory, 25(2), pp. 170-191.

Holmstrom, L. L., Karp, D. A., \& Gray, P. S. 2002. Why Laundry, Not Hegel? Social Class, Transition to College, and Pathways to Adulthood. Symbolic Interaction, 25(4), pp. 437-462.

Kroger, J., Martinussen, M., \& Marcia, J.E. 2010. Identity Status Change during Adolescence and Young Adulthood: A Meta-Analysis. Journal of Adolescence, 33(5), pp. 683-698.

Kroger, J., \& Marcia, J. E. 2011. The identity statuses: Origins, Meanings, and Interpretations. In Schwartz S. J. et al. eds. Handbook of Identity Theory and Research. New York: Springer. Vol. 1, pp. 31-53.

Lannegrand-Willems, L., \& Bosma, H. A. 2006. Identity Development-in-Context: The School as an Important Context for Identity Development. Identity, 6(1), pp. 85-113.

Macmillan, R. 2007. 'Constructing Adulthood': Agency and Subjectivity in the Transition to Adulthood. In: Macmillan R. ed. Constructing Adulthood. Agency and Subjectivity in Adolescence and Adulthood. Oxford-Amsterdam: Elsevier, pp. 3-29.

McLean, M., \& Abbas, A. 2011. Introduction to Biographical Methods. Enhancing Learning in the Social Sciences, 3(3), pp. 1-3.

Mortimer, J.T. 1996. Social psychological aspects of achievement. In A. Kerckhoff, Generating Social Stratification: Toward a New Research Agenda. New York: Routledge, pp. 17-36.

OECD 1987. Adults in Higher Education, OECD Publication 55(2), pp. 115-131. 
Pascarella, E.T. 2006. How College Affects Students: Ten Directions for Future Research. Journal of College Student Development, 47(5), pp. 508-520.

Reifman, A., Arnett, J. J., \& Colwell, M. J. 2007. Emerging adulthood: Theory, assessment, and application. Journal of Youth Development, 2(1), pp. 1-12.

Schwartz, S. J. et al. 2013. Identity in emerging adulthood: Reviewing the field and looking forward. Emerging adulthood, 1(2), pp. 96-113.

Soares, L. 2013. Post-traditional Learners and the Transformation of Postsecondary Education: A Manifesto for College Leaders. American Council on Education. retrieved from: https://www.acenet.edu/Documents/Post-traditional-Learners. pdf [October 13, 2020].

Soenens, B., \& Vansteenkiste, M. 2011. When Is Identity Congruent with the Self? A Self-Determination Theory Perspective. In: Schwartz S. J. et al. eds. Handbook of Identity Theory and Research (Vol. 1 Structures and Processes). New York-DordrechtHeidelberg-London, Springer, pp. 381-402.

Syed, M. 2016. Emerging Adulthood: Developmental Stage, Theory, or Nonsense? In: Arnett J. J. ed. The Oxford Handbook of Emerging Adulthood. New York, Oxford University Press, pp. 11-25.

Syed, M. \& McLean, K. 2015. The Future of Identity Development Research: Reflections, Tensions, and Challenges. In McLean K. C. \& Syed M. U. eds. The Oxford Handbook of Identity Development. Oxford-New York: Oxford University Press, pp. 562-573.

Tangney, S. 2013. Student-centred learning: a humanist perspective. Teaching in Higher Education, 19(3), pp. 266-275.

Thunborg, C., Bron, A., \& Edström, E. 2013. Motives, commitment and student identity in higher education-experiences of non-traditional students in Sweden. Studies in the Education of Adults, 45(2), pp. 177-193.

Toguchi Swartz, T., Hartmann, D., \& Rumbaut, R. G. eds. 2017. Crossing to Adulthood: How Diverse Young Americans Understand and Navigate Their Lives. Boston: Brill.

Waterman, A.S. 1993. Developmental Perspectives on Identity Formation. In: Marcia J. E. eds. Ego Identity: A Handbook for Psychosocial Research. New York, SpringerVerlag, pp. 42-68. 